\title{
KEMAMPUAN PEMECAHAN MASALAH MATEMATIS SISWA KELAS XI BERDASARKAN MATH ANXIETY
}

\author{
Windy Safitri ${ }^{1}$, Hella Jusra ${ }^{2}$ \\ ${ }^{1,2}$ Universitas Muhammadiyah Prof. DR. HAMKA \\ winssaf13@gmail.com \\ hella.jusra@uhamka.ac.id
}

\begin{abstract}
Abstrak
Penelitian ini bertujuan untuk mendeskripsikan tentang kemampuan pemecahan masalah matematis siswa berdasarkan math anxiety siswa. Subjek pada penelitian ini adalah siswa kelas XI SMA di Jakarta dengan jumlah 66 orang. Teknik pengumpulan data yang digunakan adalah angket Math Anxiety dan tes kemampuan pemecahan masalah matematis. Penelitian ini merupakan penelitian deskriptif statistik dengan teknik analisis data yang digunakan adalah korelasi bivariate pearson dan deskripsi data. Berdasarkan hasil penelitian ditemukan bahwa siswa yang memiliki tingkat math anxiety tinggi maka kemampuan pemecahan masalah matematis siswa rendah. Sebaliknya, siswa yang memiliki tingkat math anxiety rendah maka kemampuan pemecahan masalah matematis siswa tinggi.

Kata Kunci: Kemampuan Pemecahan Masalah Matematis, Math Anxiety
\end{abstract}

\begin{abstract}
This study aims to describe the students' mathematical problem solving abilities based on students' Math Anxiety. The subject of this research are students grade 11 in high school in Jakarta with a total of 66 people. Data collection techniques used were Math Anxiety questionnaires and tests of mathematical problem solving abilities. This study is a statistic descriptive with the data analysis technique used is Pearson bivariate correlation and observation data. Based on the results of the study found that students who have high levels of math anxiety then the students' mathematical problem solving abilities are low. Likewise, students who have low levels of math anxiety have high students' mathematical problem solving abilities.

Keywords: Mathematical Problem Solving ability, Math Anxiety
\end{abstract}

\section{PENDAHULUAN}

Pada era sekarang teknologi dan dunia semakin terhubung, sangat penting untuk membentuk kepercayaan diri siswa terhadap kemampuan mereka dalam berbagai subjek baik akademik ataupun non-akademik. Pada subjek akademik, siswa diminta untuk dapat memfokuskan kemampuan mereka dalam bidangbidang ilmu pengetahuan, khususnya dalam mata pelajaran matematika. Menurut Hudoyo [1] pemfokusan matematika dilakukan karena matematika adalah pondasi dalam menumbuhkan ilmu, sehingga dibutuhkan tenaga penuh yang cekatan serta ahli dalam matematika. Pembelajaran matematika yang diajarkan selaras dengan tujuan pembelajaran akan memperoleh hasil yang berfaedah di masa mendatang apabila dalam pembelajaran tidak terdapat hambatan-hambatan. Selama pembelajaran matematika terkadang terdapat hambatan-hambatan untuk mewujudkan tujuan pembelajaran. Hambatan tersebut dapat terlihat baik dari siswa, guru, dan lingkungan ataupun dari matematika itu sendiri. 
Hambatan-hambatan yang muncul saat pembelajaran matematika terkadang sering mempengaruhi kinerja matematika siswa. Menurut OECD (Organization for Economic Co-operation and Development) [2] kinerja matematika siswa untuk usia 15-16 tahun di negara-negara OECD lebih rendah dari rata-rata skor matematika PISA (Programme for International Students Assessment) pada tahun 2018, termasuk negara Indonesia. Pada PISA 2015 skor matematika yang diperoleh siswa Indonesia yakni sebesar 386 dari rata-rata skor matematika sebesar 490. Sedangkan, PISA 2018 sebesar 379 dari rata-rata skor matematika sebesar 489 [2][3]. Berdasarkan uraian tersebut, skor matematika atas siswa Indonesia pada PISA 2018 lebih rendah daripada PISA 2015, yang berarti skor matematika mengalami penurunan. Dengan demikian, kinerja matematika siswa Indonesia di tahun 2018 mengalami penurunan dibandingkan dengan kinerja matematika di tahun 2015. Kinerja matematika siswa dapat dipengaruhi karena beberapa faktor, yaitu kemampuan pemecahan masalah matematis, pemikiran dan kebenaran matematis, komunikasi matematika, koneksi matematika, dan penggambaran [4]. Faktor-faktor tersebut harus mampu dikuasai siswa untuk mendapatkan kinerja matematika yang baik.

Matematika juga merupakan suatu usaha yang dilakukan oleh manusia dengan bersungguh-sungguh sampai mendapatkan kondisi yang di maksud atau di kehendaki [5]. Matematika memegang kedudukan yang besar dalam mengembangkan pikiran manusia, membuat sebuah strategi, dan melakukan proses berpikir secara sistematis yang digunakan dalam kajian dan pemecahan masalah [6]. Pemecahan masalah adalah teknik kognitif yang dihadapkan untuk menggapai tujuan saat sebuah masalah tidak memiliki metode solusi yang jelas atau tetap bagi pemecah masalah [7]. Hal tersebut berperan penting dalam matematika serta dalam kehidupan sehari-hari, terutama untuk siswa. Siswa sebagai pemecah masalah harus dapat menangkap maksud dari suatu masalah, merumuskan sebuah rencana penyelesaian, menyelesaikan rencana sesuai rencana penyelesaian, dan memverifikasi ulang masalah yang telah diselesaikan [8]. Hal tersebut memperlihatkan bahwa kemampuan pemecahan masalah matematis ialah satu kemampuan primer yang dikembangkan, serta dapat menunjang siswa dalam memahami suatu masalah dan merumuskan rencana penyelesaian secara mandiri, sehingga dapat memecahkan masalah tertentu yang non rutin.

Kemampuan pemecahan masalah ialah suatu kecakapan matematika yang bersifat mandiri. Kemampuan pemecahan masalah dipengaruhi 2 faktor, yaitu faktor kognitif dan non-kognitif [9][10]. Faktor kognitif dan non-kognitif saling mempengaruhi terhadap kemampuan pemecahan masalah. Namun, menurut beberapa penelitian [7][9][11] faktor non-kognitif memiliki dampak yang lebih dominan dibandingkan faktor kognitif. Faktor non-kognitif terdiri dari kecemasan matematika (math anxiety), self-efficacy matematika, self-concept matematika, motivasi matematika, dan perilaku atas matematika [12]. Kecemasan matematika adalah satu dari beberapa faktor non-kognitif yang dipengaruhi oleh sisi psikologi, yaitu aspek emosional [13][14]. Kecemasan matematika dapat diartikan sebagai perasaan tegang, gelisah, atau takut terhadap kinerja matematika [15]. Siswa sering merasakan cemas dan takut ketika pembelajaran matematika khususnya dalam mengerjakan sebuah tes, kondisi ini dapat disebabkan karena siswa merasa tidak bisa atau tidak mampu di dalam pembelajaran matematika. 
Selain itu, dalam proses pembelajaran matematika siswa merasa gagal jika tidak mampu menyelesaikan persoalan matematika. Kondisi lainnya yang dimiliki siswa adalah sikap negatif yang didapatkan dari guru atau karena faktor kognitif [16]. Kecemasan matematika dapat diartikan dengan suatu perasaan khawatir dan tegang, sehingga siswa tidak mampu untuk melakukan pemecahan masalah dalam memanipulasi dan memodifikasi angka dan aljabar dalam permasalahan kontekstual [17]. Kecemasan matematika diukur berdasarkan pada behavioral, cognitive, dan competence [18]. Behavioral merupakan suatu sikap/perilaku siswa yang timbul ketika berkaitan dengan matematika. Cognitive merupakan suatu proses kognitif siswa ketika mengahadapi matematika. Competence merupakan suatu kompetensi yang ada pada siswa yang berkaitan dengan matematika. Hal yang didasari tersebut dapat dilihat ketika proses pembelajaran matematika di kelas dan ketika ujian matematika. Dari kedua situasi tersebut sering menimbulkan perasaan khawatir bagi siswa, sehingga siswa sering merasa takut atau tegang ketika menghadapi situasi tersebut.

Penelitian ini didasari oleh penelitian yang dilakukan Özcan \& Gümüş [11] yang memaparkan pengaruh langsung dan tidak langsung kepada kemampuan pemecahan masalah matematis melalui faktor non-kognitif. Bertujuan untuk mendeskripsikan kemampuan pemecahan masalah matematis secara spesifik yang berdasarkan salah satu faktor non-kognitif, yaitu math anxiety. Peneliti berharap urgensi penelitian ini dapat memberikan ilmu pengetahuan dan meningkatkan mutu pembelajaran matematika.

\section{METODE}

Bentuk penelitian ini merupakan deskriptif statistik. Penelitian ini menggunakan analisis statistika dan deskripsi data yang memiliki tujuan untuk mendeskripsikan kemampuan pemecahan masalah matematis siswa berdasarkan pada math anxiety siswa. Sampel penelitian siswa kelas XI SMAN di Jakarta yang berjumlah 66 orang. Data yang digunakan adalah angket math anxiety yang di adaptasi dari Abbreviated Math Anxiety Rating Scale [18] dan tes kemampuan pemecahan masalah matematis yang sudah teruji validitas dan reliabilitasnya. Angket math anxiety terdiri dari 24 item pernyataan dan tes kemampuan pemecahan masalah terdiri dari 8 butir soal dengan materi barisan dan deret yang berbentuk uraian. Tes divalidasi terhadap siswa yang bukan siswa responden, dari validasi tersebut dinyatakan 8 butir soal yang divalidasi adalah valid.

Prosedur penelitian ini adalah siswa diminta mengisi angket terlebih dahulu, kemudian masing-masing siswa mengerjakan tes kemampuan pemecahan masalah matematis secara mandiri dengan batas waktu yang tertentu. Data yang terkumpul dilakukan penskoran untuk mengetahui tingkat kecemasan matematika (math anxiety) dan tingkat kemampuan pemecahan masalah siswa sesuai dengan Tabel 1. Untuk kemampuan pemecahan masalah matematis sesuai dengan indikator pedoman penskoran kemampuan pemecahan masalah matematis pada Tabel 2 [19]. Setelah penskoran, dilakukan analisis korelasi pearson dengan menggunakan aplikasi SPSS 24.0 dan menentukan interpretasi sesuai dengan Tabel 3 [20]. 
TABEL 1 Klasifikasi Skor.

\begin{tabular}{lll}
\hline \multicolumn{1}{c}{ Skor Math Anxiety } & \multicolumn{1}{c}{$\begin{array}{c}\text { Skor Kemampuan Pemecahan } \\
\text { Masalah Matematika }\end{array}$} & \multicolumn{1}{c}{ Klasifikasi } \\
\hline$X \geq 55$ & $X \geq 79$ & Tinggi \\
$33 \leq X<55$ & $56 \leq X<79$ & Sedang \\
$X<33$ & $X<56$ & Rendah \\
\hline
\end{tabular}

TABEL 2 Indikator Pedoman Kemampuan pemecahan Masalah Matematis.

\begin{tabular}{lll}
\hline \multicolumn{1}{c}{ Indikator } & \multicolumn{1}{c}{ Respon Terhadap Soal } & Skor \\
\hline \multirow{3}{*}{ Memahami Masalah } & Salah menginterpretasikan masalah & 0 \\
\cline { 2 - 3 } & Salah menginterpretasikan sebagian masalah & 1 \\
\cline { 2 - 3 } & Memahami masalah selengkapnya & 2 \\
\hline \multirow{3}{*}{$\begin{array}{l}\text { Merumuskan } \\
\text { Penyelesaian }\end{array}$} & Merumuskan rencana yang salah & 1 \\
\cline { 2 - 3 } & Merumuskan rencana yang benar, namun hasil tidak ada & 2 \\
\cline { 2 - 3 } & Merumuskan rencana yang benar, namun belum lengkap & 3 \\
\cline { 2 - 3 } Melaksanakan & Merumuskan rencana dan mengarahkan solusi yang benar & 4 \\
\cline { 2 - 3 } Rencana Penyelesaian & Sidak melaksanakan perhitungan & 0 \\
\cline { 2 - 3 } & Selaksanakan strategi yang benar, namun perhitungan & 1 \\
\cline { 2 - 3 } Memeriksa & Melaksanakan strategi dan mendapatkan hasil yang benar & 2 \\
\hline \multirow{2}{*}{ Kembali Hasil } & Tidak memverifikasi & 0 \\
\cline { 2 - 3 } & Memverifikasi, namun tidak selesai & 2 \\
\cline { 2 - 3 } & Memverifikasi hingga selesai & 1 \\
\hline
\end{tabular}

TABEL 3 Pedoman Interpretasi Koefisien Korelasi.

\begin{tabular}{ll}
\hline \multicolumn{1}{c}{ Interval } & \multicolumn{1}{c}{ Hubungan } \\
\hline$<0,20$ & Dianggap tidak ada \\
\hline $0,20-0,40$ & Rendah \\
\hline$>0,40-0,70$ & Cukup \\
\hline$>0,70-0,90$ & Tinggi \\
\hline$>0,90-1,00$ & Sangat Tinggi \\
\hline
\end{tabular}

\section{HASIL DAN PEMBAHASAN}

Pada penelitian ini, instrumen yang digunakan sudah dinyatakan valid dan reliabel. Berdasarkan nilai reliabilitas (Tabel 4) angket math anxiety memperoleh nilai Alpha sebesar 0,913 dengan nilai $r_{\text {tabel }}$ sebesar 0,4044 (Alpha $>r_{\text {tabel }}$ ) dan pada tes kemampuan pemecahan masalah matematis memperoleh nilai Alpha sebesar 0,758 dengan nilai $r_{\text {tabel }}$ sebesar 0,7067 (Alpha $>r_{\text {tabel }}$ ). Hal tersebut menunjukkan bahwa nilai Alpha dari angket math anxiety dan tes kemampuan pemecahan masalah matematis lebih besar daripada $r_{\text {tabel }}$ (Alpha $>r_{\text {tabel }} ; 0,913>$ 0,4044; 0,758 > 0,7067), sehingga angket math anxiety dan tes kemampuan pemecahan masalah matematis dapat dikatakan reliabel. 
TABEL 4 Nilai Reliabilitas.

\begin{tabular}{ccccc}
\hline \multicolumn{1}{c}{ Math Anxiety } & \multicolumn{3}{c}{ Kemampuan Pemecahan Masalah Matematis } \\
\hline Cronbach's Alpha & $\mathbf{N}$ & \multicolumn{2}{c}{ Cronbach's Alpha } & N \\
\hline 0,913 & 24 & 0,758 & 8 & \\
\hline
\end{tabular}

Angket yang digunakan bertujuan untuk mengetahui tingkat kecemasan matematika siswa dan tes bertujuan untuk mengetahui kemampuan pemecahan masalah matematis siswa. Sehingga, hasil yang diperoleh dari angket merupakan data math anxiety siswa dan hasil yang diperoleh dari tes merupakan data kemampuan pemecahan masalah matematis siswa. Pada angket math anxiety digunakan sebuah skala, yang berupa skala likert. Skala likert yang digunakan terdiri dari 5 skala, yaitu tidak cemas sama sekali (skor 0), sedikit cemas (skor 1), cukup cemas (skor 2), agak cemas (skor 3), dan sangat cemas (skor 4) [16]. Skor maksimum pada angket math anxiety sebesar 96 dan skor minimum sebesar 0 . Pada tes kemampuan pemecahan masalah matematis menggunakan pedoman penskoran kemampuan pemecahan masalah matematis (Tabel 2). Pada tiap butir soal memiliki skor maksimum sebesar 10, terdapat 4 butir soal yang merupakan butir soal yang bercabang, sehingga tiap butir soal tersebut memiliki skor maksimum sebesar 20. Skor maksimum tes kemampuan pemecahan masalah matematis adalah 120 dan skor minimum adalah 0 [18].

Hasil penskoran pada angket math anxiety dan tes kemampuan pemecahan masalah matematis ditampilkan pada Tabel 5, terlihat bahwa pada angket math anxiety terdapat 12 orang siswa dengan tingkat math anxiety yang tinggi memiliki persentase $18,182 \%, 36$ orang siswa dengan tingkat math anxiety yang sedang memiliki persentase $54,545 \%$, dan 18 orang siswa dengan tingkat math anxiety yang rendah memiliki persentase $27,273 \%$. Berdasarkan hasil tersebut, maka mayoritas tingkat math anxiety siswa adalah pada klasifikasi sedang. Pada tes kemampuan pemecahan masalah terdapat 23 orang siswa dengan tingkat kemampuan pemecahan masalah yang tinggi memiliki persentase 34,848\%, 39 orang siswa dengan tingkat kemampuan pemecahan masalah yang sedang memiliki persentase $59,091 \%$, dan 4 orang dengan tingkat kemampuan pemecahan masalah yang rendah memiliki persentase $6,061 \%$. Berdasarkan hasil tersebut, maka mayoritas tingkat kemampuan pemecahan masalah matematis siswa adalah pada klasifikasi sedang.

TABEL 5 Hasil Penskoran Angket Math Anxiety dan Tes Kemampuan Pemecahan Masalah Matematis.

\begin{tabular}{llllll}
\hline \multicolumn{2}{c}{ Kemampuan Pemecahan Masalah } & \multicolumn{3}{c}{ Math Anxiety } \\
\hline \multicolumn{1}{c}{ Skor } & F & \% & Skor & F & \% \\
\hline$X \geq 79$ & 23 & 34,484 & $X \geq 55$ & 12 & 18,182 \\
\hline $56 \leq X<79$ & 39 & 59,091 & $33 \leq X<55$ & 36 & 54,545 \\
\hline$X<56$ & 4 & 6,061 & $X<33$ & 18 & 27,273 \\
\hline
\end{tabular}


Hasil penyelesaian salah satu siswa yang tingkat kemampuan pemecahan masalah matematisnya tinggi (Siswa T) (Gambar 1), salah satu siswa yang tingkat kemampuan pemecahan masalah matematisnya sedang (Siswa S) (Gambar 2), dan salah satu siswa yang tingkat kemampuan pemecahan masalah matematisnya rendah (Siswa R) (Gambar 3). Ketiga siswa tersebut dipilih secara acak dilihat dari kesesuaian klasifikasi skor dan kejelasan tulisan siswa. Hasil pengerjaan yang ditampilkan adalah butir soal nomor 1. Dilihat dari jawaban, siswa T memahami dengan baik masalahnya dengan melakukan perhitungan dan kesimpulan dengan benar. Siswa S memahami dengan baik masalahnya tetapi melakukan perhitungan dan kesimpulan yang salah. Siswa $\mathrm{R}$ tidak memahami dengan baik masalahnya serta membuat perencanaan, perhitungan dan kesimpulan yang salah.

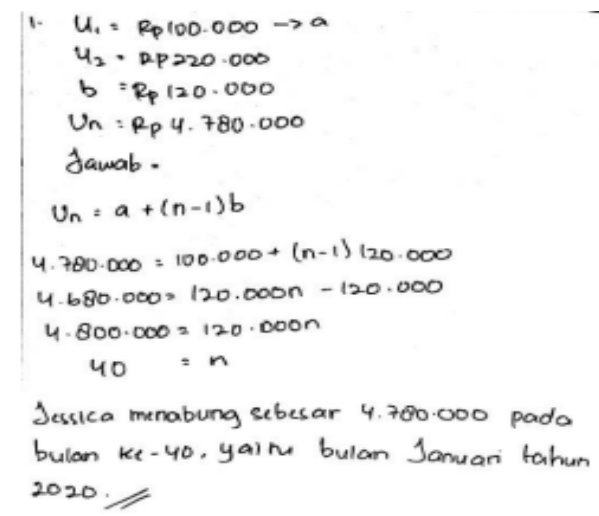

Gambar 1 Hasil Pengerjaan Siswa T

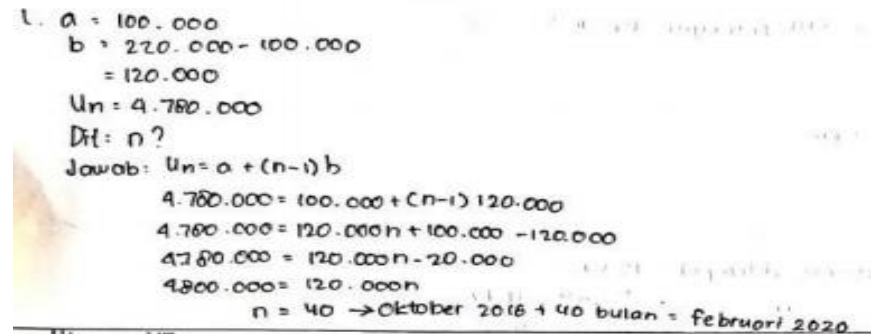

Gambar 2 Hasil Pengerjaan Siswa S

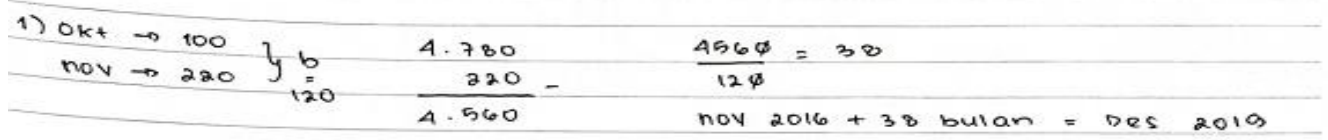

Gambar 3 Hasil Pengerjaan Siswa R 
Berdasarkan indikator pedoman penskoran kemampuan pemecahan masalah matematis siswa (Tabel 2), pada indikator 1, yaitu memahami sebuah masalah yang berarti Siswa harus menangkap maksud dari suatu masalah yang dibagikan [8]. Tetapi siswa tidak hanya harus paham atas masalah saja, siswa juga harus tertarik atau memiliki kemauan untuk menyelesaikan masalah tersebut. Siswa juga harus bisa menunjukkan inti masalah pada soal, yang tidak diketahui, data yang ada, dan kondisi masalah tersebut. Apabila masalah tidak dipahami, masalah tidak akan terselesaikan oleh siswa dengan baik. Pada siswa T terlihat bahwa siswa tersebut dapat menangkap masalah dengan menuliskan data yang tertera serta mengetahui pertanyaan dari soal, sehingga mendapatkan skor penuh, yaitu 2. Pada siswa $\mathrm{S}$ juga dapat menangkap masalah dengan menuliskan data yang tertera serta mengetahui pertanyaan dari soal, sehingga mendapatkan skor penuh, yaitu 2. Pada siswa $\mathrm{R}$ terlihat bahwa siswa tersebut sedikit memahami masalah atau mengabaikan beberapa bagian-bagian penting pada soal, seperti tidak menuliskan data yang tertera dengan lengkap meskipun mengetahui pertanyaan dari soal, sehingga mendapatkan skor 1 (Tabel 6).

Pada indikator 2, yaitu merumuskan rencana penyelesaian yang berarti siswa memiliki rencana ketika siswa mengetahui atau mengetahui setidaknya secara garis besarnya saja seperti cara perhitungan atau bentuk dari masalah. Hal tersebut harus siswa lakukan untuk mendapatkan hal yang tidak diketahui atau yang ditanyakan dari masalah. Mulai dari memahami masalah hingga menyusun sebuah rencana mungkin memakan waktu yang lama dan berbelit-belit untuk siswa. Kunci dalam pemecahan masalah ialah merancang ide perencanaan [8]. Sulit untuk siswa memiliki ide yang bagus apabila siswa hanya memiliki sedikit pengetahuan dan pengalaman tentang suatu subjek permasalahan. Apalagi siswa yang tidak memiliki pengetahuan dan pengalaman sama sekali. Pengetahuan dan pengalaman siswa sangat beragam dan berbeda-beda, sehingga dapat menumbuhkan kreatifitas siswa dalam merumuskan rencana suatu masalah. Pada siswa $\mathrm{T}$ terlihat bahwa siswa tersebut merancang rencana dan mengarahkan solusi dengan tepat, sehingga mendapatkan skor 4. Pada siswa S juga merancang rencana dan mengarahkan solusi dengan tepat, sehingga mendapatkan skor 4 . Pada siswa $\mathrm{R}$ membuat rencana yang salah dan tidak sesuai, sehingga mendapatkan skor 0 (Tabel 6).

Pada indikator 3, yaitu melaksanakan rencana penyelesaian. Untuk menyusun rencana dan memahami ide solusi itu tidak mudah. Dibutuhkan begitu banyak usaha untuk berhasil, seperti pengetahuan yang sebelumnya diperoleh, pengalaman dalam menyelesaikan masalah, konsentrasi pada tujuan, dan keberuntungan [8]. Untuk melaksanakan rencana itu jauh lebih mudah, yang siswa butuhkan hanyalah kesabaran. Rencana tersebut memberikan garis besar secara umum terhadap masalah, siswa harus meyakinkan dirinya sendiri bahwa perincian dari rencana sesuai dengan garis besar, dan karenanya siswa harus memeriksa perincian satu per satu dengan sabar hingga menyelesaikan rencana penyelesaian dengan mengarahkan pada jawaban yang tepat. Pada siswa T terlihat bahwa siswa tersebut menyelesaikan rencana penyelesaian dengan rinci dan mendapatkan jawaban yang tepat, sehingga memperoleh skor 2. Pada siswa S menyelesaikan rencana penyelesaian dengan rinci namun jawabannya salah, sehingga memperoleh skor 1. Pada siswa $\mathrm{R}$ mendapatkan jawaban yang salah karena pada 
indikator 2, siswa $\mathrm{R}$ membuat rencana yang salah, sehingga memperoleh skor 0 (Tabel 6).

Pada indikator 4, yaitu memeriksa kembali hasil. Pada tahap ini siswa sering kali mengabaikanya, setelah menyelesaikan masalahnya siswa biasanya langsung mengganti topik tanpa memeriksanya kembali. Seharusnya, siswa yang telah melaksanakan rencana penyelesaian dan mendapatkan solusi dari masalah. Siswa menuliskan solusinya, memeriksa setiap langkah penyelesaian masalahnya. Siswa juga harus memiliki alasan yang kuat untuk meyakini bahwa solusinya benar. Namun, kesalahan selalu mungkin terjadi, terutama jika penjelasannya yang panjang dan berbelit-nelit. Karenanya, pemeriksaan sangat diperlukan. Terutama, jika ada beberapa prosedur untuk menguji hasil atau penjelasan yang tidak boleh diabaikan [8]. Melakukan pemeriksaan atas apa yang dilakukan mulai dari memahami masalah sampai menyelesaikan rencana penyelesaian suatu masalah. Dengan seperti itu maka kesalahan yang ada dapat kembali terkoreksi sehingga siswa bisa mencapai jawaban yang tepat. Pada siswa $\mathrm{T}$ terlihat bahwa siswa tersebut melaksanakan indikator ke-4 ini dengan memeriksa kembali setiap langkahnya dan menuliskan penjelasan untuk memperkuat jawabannya, sehingga mendapatkan skor 2. Pada siswa $\mathrm{S}$ tidak melakukan pemeriksaan kembali, sehingga mendapatkan skor 0 . Pada siswa $\mathrm{R}$ tidak melakukan pemeriksaan kembali karena pada indikator ke-2 dan ke-3 tidak terpenuhi dengan baik, sehingga mendapatkan skor 0 (Tabel 6).

TABEL 6 Penskoran Tes Kemampuan Pemecahan Masalah Matematis .

\begin{tabular}{lccccc}
\hline & Indikator 1 & Indikator 2 & Indikator 3 & Indikator 4 & Total Skor \\
\hline Siswa T & 2 & 4 & 2 & 2 & 10 \\
\hline Siswa S & 2 & 4 & 1 & 0 & 7 \\
\hline Siswa R & 1 & 0 & 0 & 0 & 1 \\
\hline
\end{tabular}

Pada ketiga siswa tersebut didapatkan juga data math anxiety, siswa $\mathrm{T}$ memperoleh skor sebesar 26 yang termasuk ke dalam skor rendah (Tabel 1), siswa $\mathrm{S}$ memperoleh skor sebesar 42 yang termasuk ke dalam skor sedang (Tabel 1), dan siswa $\mathrm{R}$ memperoleh skor sebesar 58 yang termasuk ke dalam skor tinggi (Tabel 1). Berdasarkan pemaparan tersebut, dapat disimpulkan bahwa terdapat sebuah hubungan antara math anxiety dan kemampuan pemecahan masalah matematis. Untuk memperdalam analisis peneliti mengenai hubungan antara kecemasan matematika dan kemampuan pemecahan masalah matematis dilakukan juga analisis statistika dengan menggunakan SPSS.

Berdasarkan analisis statistika, sebaran data dari kedua variabel memiliki sebaran data yang normal. Analisis yang dilakukan adalah korelasi bivariate pearson, hasilnya ditampilkan pada Tabel 7, diperoleh hubungan korelasi sebesar $-0,330(*)$ antara kedua variabel, hal ini menyatakan adanya korelasi signifikan pada taraf signifikan $0,05(5 \%)$. Tanda negatif pada $-0,330$ menandakan arah hubungan yang berlawanan, ini berarti semakin tinggi tingkat math anxiety maka kemampuan pemecahan masalah matematis siswa semakin rendah [11]. Sebaliknya, semakin rendah tingkat math anxiety maka kemampuan pemecahan masalah matematis siswa semakin tinggi. 
TABEL 7 Hasil Korelasi Bivariate Pearson.

\begin{tabular}{|c|c|c|c|}
\hline & & Math Anxiety & Kemampuan Pemecahan Masalah \\
\hline Math Anxiety & & 1 & $-0,330 *$ \\
\hline $\begin{array}{l}\text { Kemampuan } \\
\text { Masalah }\end{array}$ & Pemecahan & $-0,330 *$ & 1 \\
\hline
\end{tabular}

Berdasarkan perhitungan uji korelasi diperoleh hasil bahwa adanya hubungan antara math anxiety dan kemampuan pemecahan masalah matematika matematis secara signifikan. Dengan dinyatakannya nilai Sig. sebesar 0,007 dan $\alpha$ $=0,05$, sehingga nilai Sig. $<0,05(0,007<0,05)$. Diperoleh juga nilai r sebesar 0,330 yang menunjukkan besar hubungan antara math anxiety dan kemampuan pemecahan masalah matematika matematis. Berdasarkan Tabel 3, nilai 0,330 termasuk dalam interval $0,20-0,40$ dan termasuk dalam hubungan yang rendah. Hal tersebut menyatakan bahwa besar korelasi math anxiety dengan kemampuan pemecahan masalah matematis adalah lemah. Nilai $r$ memiliki tanda negatif, maka math anxiety dan kemampuan pemecahan masalah matematika matematis memiliki hubungan yang berlawanan, yang berarti semakin tinggi tingkat math anxiety maka kemampuan pemecahan masalah matematis siswa semakin rendah. Sebaliknya, semakin rendah tingkat math anxiety maka kemampuan pemecahan masalah matematis siswa semakin tinggi.

Berdasarkan hasil analisis dan deskripsi, peneliti menemukan bahwa terdapat beberapa hambatan kemampuan pemecahan masalah matematis yang terlihat. Pertama, siswa sulit untuk menangkap maksud dari masalah yang dibagikan dikarenakan siswa tidak mengetahui secara lengkap data yang terdapat pada masalah yang dibagikan. Kedua, siswa tidak memiliki atau tidak menguasai pengetahuan tentang materi yang dujikan, sehingga siswa tidak mampu untuk menyelesaikan masalah yang dibagikan. Ketiga, beberapa siswa merasa adanya tekanan dalam menyelesaikan masalah sehingga siswa tidak bisa menyelesaikan masalah yang dibagikan dengan baik. Keempat, dalam menyelesaikan masalah beberapa siswa sangat terpaku pada waktu dan butir soal yang diberikan sehingga dalam menyelesaikan masalah siswa menjadi panik dan terburu-buru yang menyebabkan penyelesaian masalah yang dibagikan tidak diselesaikan dengan baik.

Berdasarkan hasil tersebut, maka hasil tersebut sesuai dengan penelitian Özcan \& Gümüş [11] yang pada hasil penelitiannya menyatakan bahwa kecemasan matematika memiliki korelasi yang rendah dan negatif terhadap kemampuan pemecahan masalah matematis.

\section{KESIMPULAN}

Berdasarkan perhitungan dan analisis didapatkan 18,182\% siswa dengan tingkat math anxiety yang tinggi, 54,545\% siswa memiliki tingkat math anxiety yang sedang, dan $27,273 \%$ siswa memiliki tingkat math anxiety yang rendah. Serta, $34,848 \%$ siswa memiliki kemampuan pemecahan masalah yang tinggi, $59,091 \%$ siswa memiliki kemampuan pemecahan masalah matematis yang sedang, dan 6,061\% siswa memiliki kemampuan pemecahan masalah matematis 
yang rendah, sehingga mayoritas siswa memiliki tingkat math anxiety dan kemampuan pemecahan masalah matematis yang sedang.

Hasil penelitian juga menunjukkan bahwa math anxiety dan kemampuan pemecahan masalah matematika matematis pada siswa kelas XI SMAN di Jakarta terdapat sebuah hubungan. Berdasarkan deskripsi disimpulkan bahwa siswa yang kemampuan pemecahan masalah matematisnya tinggi mempunyai tingkat math anxiety yang rendah (Siswa T), siswa yang kemampuan pemecahan masalah matematisnya sedang mempunyai tingkat math anxiety yang sedang (Siswa S), dan siswa yang kemampuan pemecahan masalah matematisnya rendah mempunyai tingkat math anxiety yang tinggi (Siswa R).

\section{DAFTAR RUJUKAN}

[1] Saputra, P. R. (2014). Kecemasan Matematika Dan Cara Menguranginya ( Mathematic Anxiety and How To Reduce It ). Pyhthagoras Jurnal Pendidikan Matematika Unrika, 3(2), 75-84.

[2] OECD. (2019). PISA 2018 Results (Volume I): What Students Know and Can Do. Paris: OECD Publishing.

[3] OECD. (2018). PISA 2015 Results in Focus. Paris: OECD Publishing

[4] NCTM. (2002). Principles and Standards for School Mathematics. Retrieved from www.nctm.org

[5] Mann, E. L., Chamberlin, S. A., \& Graefe, A. K. (2017). The Prominence of Affect in Creativity: Expanding the Conception of Creativity in Mathematical Problem Solving. In Leikin R., Sriraman B. (eds) Creativity and Giftedness (pp. 57-73). Advances in Mathematics Education. https://doi.org/https://doi.org/10.1007/978-3-319-38840-3_5

[6] Phonapichat, P., Wongwanich, S., \& Sujiva, S. (2014). An Analysis of Elementary School Students' Difficulties in Mathematical Problem Solving. Procedia - Social and Behavioral Sciences, 116(2012), 3169-3174. https://doi.org/10.1016/j.sbspro.2014.01.728

[7] Lai, Y., Zhu, X., Chen, Y., \& Li, Y. (2015). Effects of mathematics anxiety and mathematical metacognition on word problem solving in children with and without mathematical learning difficulties. PLoS ONE, 10(6), 1-19. https://doi.org/10.1371/journal.pone.0130570

[8] Polya, G. (2004). How to Solve It: A New Aspect of Mathematical Method. With a new foreword by John H. Conway. United States of America: Princeton University Press.

[9] Hoffman, B. (2010). "I think I can, but I'm afraid to try": The role of self-efficacy beliefs and mathematics anxiety in mathematics problem-solving efficiency. Learning and Individual Differences, 20(3), 276-283. https://doi.org/10.1016/j.lindif.2010.02.001

[10] Kramarski, B., Weisse, I., \& Kololshi-Minsker, I. (2010). How can self-regulated learning support the problem solving of third-grade students with mathematics anxiety? ZDM International Journal on Mathematics Education, 42(2), 179-193. https://doi.org/10.1007/s11858-009-0202-8

[11] Özcan, Z. Ç., \& Gümüş, A. E. (2019). A modeling study to explain mathematical problemsolving performance through metacognition, self-efficacy, motivation, and anxiety. Australian Journal of Education, 63(1), 116-134. https://doi.org/10.1177/0004944119840073

[12] Pitsia, V., Biggart, A., \& Karakolidis, A. (2017). The role of students ' self-beliefs , motivation and attitudes in predicting mathematics achievement: A multilevel analysis of the Programme for International Student Assessment data. Learning and Individual Differences, 55, 163-173. https://doi.org/10.1016/j.lindif.2017.03.014

[13] Henschel, S., \& Roick, T. (2017). Relationships of mathematics performance, control and value beliefs with cognitive and affective math anxiety. Learning and Individual Differences, 55, 97-107. https://doi.org/10.1016/j.lindif.2017.03.009

[14] Passolunghi, M. C., Caviola, S., De Agostini, R., Perin, C., \& Mammarella, I. C. (2016). Mathematics anxiety, working memory, and mathematics performance in secondary-school children. Frontiers in Psychology, 7(FEB), 1-8. https://doi.org/10.3389/fpsyg.2016.00042 
[15] Ashcraft, M. H. (2002). Math Anxiety: Personal, Educational, and Cognitive Consequences. Current Directions in Psychological Science, 11(5), 181-185. https://doi.org/10.1111/1467$\underline{8721.00196}$

[16] Skagerlund, K., Östergren, R., Västfjäll, D., \& Träff, U. (2019). How does mathematics anxiety impair mathematical abilities? Investigating the link between math anxiety, working memory, and number processing. PLoS ONE, 14(1), 1-17. https://doi.org/10.1371/journal.pone.0211283

[17] Mutlu, Y. (2019). Math anxiety in students with and without math learning difficulties. International Electronic Journal of Elementary Education, 11(5), 471-475. https://doi.org/10.26822/iejee.2019553343

[18] Ashcraft, M. H., \& Kirk, E. P. (2001). The Relationships Among Working Memory, Math Anxiety, and Performance. Journal of Experimental Psychology: General, 130(2), 224-237. https://doi.org/10.1037//0096-3445.130.2.224

[19] Sundawan, M. D. (2014). Pengaruh Penggunaan Model Pembelajaran Konstruktivisme Terhadap Kemampuan Pemecahan Masalah Matematik Siswa. Jurnal Euclid, 1(2), 125-136. https://doi.org/10.33603/e.v1i2.351

[20] Sarwono, J. (2006). Metode Penelitian Kuantitatif \& Kualitatif. Yogyakarta: Penerbit Graha Ilmu. 